\title{
Management of anthracnose in soybean caused by Colletotrichum truncatum
}

\section{S.L. KALE* AND B.G. BARHATE}

Department of Plant Pathology and Agricultural Microbiology, Mahatma Phule Krishi Vidyapeeth, Rahuri, Ahemednagar (M.S.) INDIA

\section{ARITCLE INFO}

Received : 03.08 .2016

Revised : 11.09 .2016

Accepted : 25.09.2016

\section{KEY WORDS :}

Glycine max, Anthracnose,

Colletotrichum truncatum, Fungicides,

Bioagents

*Corresponding author:

Email : savitakale417@gmail.com

\section{ABSTRACT}

A study was conducted in the Department of Plant Pathology and Agricultural Microbiology, Mahatma Phule Krishi Vidyapeeth, Rahuri, Ahemednagar,Maharashtra during 2014 to 2015 to control Colletotrichum truncatum causing anthracnose or pod blight of soybean with fungicides and bioagents. All the fungicides and bioagents evaluated in vitro were found effective against $C$. truncatum and recorded significant inhibition of the test pathogen over untreated control. However, carbendazim was found most effective and recorded $0.66 \mathrm{~mm}$ mean colony diameter and significantly highest growth inhibition $(99.26 \%)$ of the test pathogen. This was followed by mancozeb $(98.88 \%)$, hexaconazole $(84.44 \%)$, chlorothalonil $(80.00 \%)$, propiconazole $(78.15 \%)$ and difenconazole $(32.22 \%)$. Out of the six bioagents evaluated in vitro T. viride and $T$. harzianum recorded significantly highest growth inhibition $(78.88 \%)$ followed by $T$. hamatum (77.04\%), yeast (40.37\%), P. fluorescens $(27.77 \%)$ and mehandi leaf extract $(17.77 \%)$. In vitro physiological study of pathogen shows that $C$. truncatum grew well at $27^{\circ} \mathrm{C}$ temperature with 75 per cent relative humidity.

How to view point the article : Kale, S.L. and Barhate, B.G. (2016). Management of anthracnose in soybean caused by Colletotrichum truncatum. Internat. J. Plant Protec., 9(2) : 583-588, DOI : 10.15740/HAS/IJPP/9.2/583-588. 